\title{
IMPLEMENTASI PRINSIP GOOD CORPORATE GOVERNANCE PADA PERBANKAN SYARI'AH DI INDONESIA
}

\author{
Nur Hidayati Setyani.
}

\begin{abstract}
Bank is financial institution, which is a fungtioning financial intermediary from two parties, namely sides that excess fund and poor one party lents fund. Principle syari'ah is ruling indentured base islamic law among bank and party othering to keep fund and/or business activity finanance, or stated another activity according to syari'ah.Good corporate governance $(G C G)$ is manner brings of bank that are principles apply; transparency, accountability, responsibility, independency and fairness. GCG's principles really back up syar'i. In Islam also recognized many muamalah's principles as; justice, tazawun, masuliyah, behaviour, shiddiq, trust, fathanah, tabligh hurriyah, charity, wasathan, ghirah, idarah, khalifah, aqidah, ijabiyah, raqabah, qira'ah and islah. Implementation about performing GCG at various institute carries on business to get profit's orientation, notably financial institution/syari'ah bank, constitute a certainty, even syari'ah's financial institutions in particular bank syari'ah, ought to becomes pionir, since to carried on terminological islamic principles.
\end{abstract}

Keywords : Good Corporate Governance, Syari’ah’s banking, Implementasi.

\section{PENDAHULUAN}

Perbankan syari'ah mempunyai peran yang sangat strategis dalam upaya pengembanganan ekonomi kerakyatan, karena bank syari'ah berorientasi pada manfaat bukan pada maksimalisasi keuntungan semata. Transaksi di bank syari'ah juga riil bukan spekulatif, kemitraan yang dibangun bukan debitor-kreditor, usaha yang dibiayai pun harus halal bukan hanya profitable oriented semata, dan yang paling penting ialah bahwa bank syari'ah memberlakukan uang sebagai instrumen bukan komoditas. Meskipun bank syari'ah secara hakiki memang tidak bisa terlepas dari orientasi bisnis, namun justru pengembangan dan penegakan ajaran Islam dalam bermuamalah disegala transaksi merupakan tujuan utama. Oleh karenanya konsep dasar dari bank syari'ah adalah untuk mencari keuntungan di dunia dan akhirat.

Ketika krisis ekonomi berkepanjangan melanda negeri ini, bank-bank konvensional di Indonesia yang menerapkan sistem bunga telah gagal dalam menjalankan fungsi intermediasinya. Hal itu terlihat dari banyaknya bank konvensional yang kolaps karena virus negative spread. Pada saat krisis ekonomi, tidak satu senpun dana rekapitulasi yang

\footnotetext{
${ }^{1}$ Dosen Fakultas Syari'ah IAIN Walisongo Semarang;

E-mail: nur_hidayati@yahoo.co.id
} 
dikeluarkan pemerintah untuk menolong bank syari'ah sehingga bank syari'ah tidak perlu menjadi pasien BPPN seperti umumnya bank-bank konvensional.

Dalam “Outlook Perbankan Syari' ah Indonesia 2008”, yang diterbitkan BI, disebutkan bahwa selama tahun 2007 dana pihak ketiga (DPK) yang dihimpun bank syari'ah Rp. 24,7 triliun atau mencapai $32,7 \%$. Sesungguhnya potensi perkembangan industri syari'ah di Indonesia sangat besar karena perekonomian negara ini masih akan terus tumbuh pada masa datang. Apalagi saat ini banyak sektor yang perlu dibangun dan tentu saja itu semua membutuhkan pendanaan. ${ }^{2}$ Namun demikian perbankan syari'ah di Indonesia saat ini belum mampu menghasilkan produk yang sepenuhnya memenuhi kebutuhan konsumen dan pola pemasaran produk syari'ah masih dilakukan dengan konservatip. Akibatnya produk perbankan syari'ah kurang dikenal masyarakat luas. ${ }^{3}$

Sebagaimana diketahui bahwa, memasuki abad ke-21, tuntutan untuk pelaksanaan tata kelola perusahaan yang baik (good corporate governance,/GCG) dalam pengelolaan perbankan sangat penting segera dilakukan. Pemicu utama berkembangnya tuntutan ini diakibatkan oleh krisis yang terjadi di sektor perbankan yang umumnya didominasi oleh perbankan konvensional pada pertengahan tahun 1997 yang terus berlangsung sampai tahun 2000. Usaha mengembalikan kepercayaan kepada dunia perbankan Indonesia melalui restrukturisasi dan rekapitalisasi hanya dapat mempunyai dampak jangka panjang dan mendasar apabila disertai tiga tindakan penting lain yaitu : (i) Ketaatan terhadap prinsip kehati-hatian; (ii) Pelaksanaan good corporate governance; dan (iii) Pengawasan yang efektif dari Otoritas Pengawas Bank.

Berdasarkan beberapa hasil penelitian dan laporan dari Bank Dunia dan ADB krisis perbankan yang terjadi di Indonesia dan keruntuhan perusahaan-perusahaan besar dunia disebabkan oleh karena buruknya pelaksanaan praktik-praktik GCG. Secara yuridis prinsipprinsip GCG yang telah ditetapkan oleh BI dalam Peraturan Bank Indonesia (PBI) No. 8/4/PBI/2006 dan diubah dalam Peraturan Bank Indonesia No. 8/14/PBI/2006 tentang Pelaksanaan Good Corporate Governance bagi Bank Umum. Di dalam Undang-Undang No 21 Tahun 2008 tentang Perbankan Syari'ah, ditentukan bahwa dalam melaksanakan usahanya, bank syari'ah dan UUS wajib memenuhi tata kelola perusahaan yang baik (good corporate governance), prinsip kehati-hatian dan pengelolaan resiko. Selain itu bank syari'ah dan UUS diwajibkan pula untuk menerapkan prinsip mengenal nasabah dan perlindungan nasabah termasuk kewajiban untuk menjelaskan kepada Nasabah mengenai kemungkinan timbulnya resiko kerugian sehubungan dengan transaksi nasabah yang dilakukan melalui Bank Syari'ah. ${ }^{4}$

\section{TELAAH TEORITIS}

\section{Perbankan Islam di Indonesia}

Perbankan syari'ah dalam peristilahan internasional dikenal sebagai Islamic banking ${ }^{5}$ atau terkadang juga dikenal sebagai perbankan tanpa bunga (interest - free banking) ${ }^{6}$. Pada

\footnotetext{
${ }^{2}$ Tjahja Gunawan Diredja, Industri Perbankan Syari'ah Perdebatan Dangkal Soal Riba, Kompas, Senin 11Februari 2008 $2 / 30 / 2010$

3 http;/www.fiscal.depkeu.go.id/bapekki/klip/detailklip.asp?klipID=N267363402 diakses tanggal

${ }_{5}^{4}$ Undang-undang No. 21 Tahun 2008, tentang Perbankan Syari'ah, pasal 34, 35, 38 dan 39

${ }^{5}$ Penggunaan kata Islamic banking tidak terlepas dari asal-usul system perbankan syari'ah yang pada awalnya dikembangkan sebagai suatu respon dari kelompok ekonom dan praktisi perbankan muslim yang berusaha mengakomodir desakan dari berbagai pihak yang menginginkan agar tersedia jasa transaksi keuangan yang dilaksanakan sejalan dengan nilai moral dan prinsip-prinsip syari'ah Islam khususnya yang berkaitan dengan pelarangan praktek riba, kegiatan yang bersifat spekulatif yang serupa dengan praktek perjudian (maysir), ketidakjelasan (gharar) dan pelanggaran prinsip keadilan dalam bertransaksi, serta keharusan
} 
umumnya para pakar perbankan syari'ah menolak penyederhanaan perbankan syari'ah sebagai bank tanpa bunga, perbankan syari'ah tidak dikembangkan dengan hanya menghilangkan unsur riba (bunga) dalam transaksi keuangan, namun lebih dari itu dengan mengadopsi seluruh prinsip-prinsip keadilan, dalam ajaran agama serta menerapkan hukum, prosedur dan instrumen keuangan yang dapat memelihara dan menjamin terlaksananya keadilan, persamaan, dan tegaknya nilai-nilai moral dalam kegiatan keuangan. Selanjutnya perbankan syari'ah tidak-semata-mata dikaitkan dengan masalah tuntutan pemenuhan ketentuan agama, tetapi lebih ditekankan pada advantages yang dapat ditawarkannya, baik secara mikro bagi pengguna jasa dan investor maupun secara makro bagi sistem perekonomian secara keseluruhan, oleh karena itu perbankan syari'ah adalah sistem yang dapat dipakai dan dioperasikan oleh siapa saja, tidak hanya masyarakat muslim. Dalam khazanah keilmuan Islam istilah bank tidak dikenal, yang dikenal adalah istilah Jihbiz ${ }^{7}$.

Eksistensi Bank Islam secara hukum positif dimungkinkan pertama kali melalui Pasal 6 huruf m Undang-undang No. 7 Tahun 1992 tentang Perbankan Pada tahun 1998 eksistensi Bank Islam lebih dikukuhkan dengan dikeluarkannya Undang-undang No. 10 Tahun 1998 tentang Perubahan Atas Undang-undang No. 7 Tahun 1992 tentang Perbankan. Dalam Undang-undang tersebut, sebagaimana ditetapkan dalam angka 3 jo. angka 13 Pasal 1 Undang-undang No. 10 Tahun 1998, penyebutan terhadap entitas perbankan Islam secara tegas diberikan dengan istilah Bank Syari'ah atau Bank Berdasarkan Prinsip Syari'ah. Pada tanggal 12 Mei 1999.

Pada tanggal 9 Januari 2004 diterbitkan Arsitektur Perbankan Indonesia (API) sebagai blueprint perbankan nasional, yang merupakan kelanjutan dari program restrukturisasi perbankan yang sudah berjalan sejak tahun 1998. API adalah kerangka dasar sistem perbankan Indonesia yang bersifat menyeluruh dan memberikan arah, bentuk dan tatanan industri perbankan untuk waktu lima sampai sepuluh tahun ke depan. API dilandasi oleh visi mencapai suatu sistem perbankan yang sehat, kuat, dan efisien guna menciptakan kestabilan sistem keuangan dalam rangka membantu mendorong pertumbuhan ekonomi nasional. ${ }^{8}$

Arsitektur Perbankan Indonesia secara prinsip berlaku pula untuk perbankan syari'ah, namun mengingat kekhususanya, maka dalam rangka pengembangan perbankan syari'ah telah ditetapkan dalam cetak biru, yang diantaranya memuat acuan yang dapat dilakukan perbankan syari'ah, yaitu berpegang pada empat pilar yang meliputi; pertama, kepatuhan pada prinsip syari'ah; kedua, pembentukan regulasi kehati-hatian; ketiga, efisiensi dan daya saing; keempat mendukung stabilitas sistem keuangan dan kemanfaatan terhadap ekonomi. ${ }^{9}$

Menurut Abdul Ghofur Anshori, pelaksanaan sistem syari'ah pada perbankan syari'ah dapat dilihat dari 2 (dua) prespektif yakni perspektif mikro maupun perspektif makro. Nilainilai syari'ah dalam perspektif mikro menghendaki bahwa semua dana yang diperoleh dalam sistem perbankan syari'ah dikelola dengan integritas tinggi dan sangat hati-hati. Nilai-nilai syari'ah dalam perspektif mikro meliputi ${ }^{10}$ : (1) Shiddiq, yaitu memastikan bahwa pengelolaan bank syari'ah dilakukan dengan moralitas yang menjunjung tinggi nilai

penyaluran pembiayaan dan investasi pada kegiatan usaha yang etis (ethical investment) dan halal secara syari'ah.

${ }^{6}$ Istilah perbankan tanpa bunga (interest free banking) banyak dipergunakan oleh karena keunikan yang paling menonjol dari system syari'ah adalah pelarangan penggunaan instrument bunga dalam seluruh kegiatan usahanya.

${ }^{7}$ Kata Jihbiz berasal dari bahasa Persia yang berarti penagih pajak. Istilah Jihbiz mulai dikenal dijaman Mu'awiyah, yang ketika itu fungsinya sebagai penagih pajak dan penghitung pajak atas barang dan tanah.

${ }^{8}$ Bank Indonesia, Arsitek Perbankan Indonesia, Jakarta, Bank Indonesia, 2006.

${ }^{9}$ Muhamad Djumhana, Asas-Asas Hukum Perbankan Indonesia, Bandung, Citra Aditya Bakti, 2008, hal.23

${ }^{10}$ Abdul Ghofur Anshori, Perbankan Syari'ah Di Indonesia, Yogyakarta, Gadjah Mada University Press, 2007, hal 170. 
kejujuran. Nilai ini mencerminkan bahwa pengelolaan dana masyarakat akan dilakukan dengan mengedepankan cara-cara yang diperkenankan (halal) serta menjauhi cara-cara yang meragukan (Syubhat) terlebih lagi yang bersifat dilarang (haram); (2) Tabligh, dimana secara berkesinambungan melakukan sosialisasi dan mengedukasi masyarakat mengenai prinsipprinsip, produk dan jasa perbankan syari'ah. Dalam melakukan sosialisasi sebaiknya tidak hanya mengedepankan pemenuhan prinsip syari'ah semata, tetapi juga harus mampu mengedukasi masyarakat mengenai manfaat bagi pengguna jasa perbankan syari'ah; (3) Amanah, artinya menjaga dengan ketat prinsip kehati-hatian dan kejujuran dalam mengelola dana yang diperoleh dari pemilik dana (shahibul maal) sehingga timbul rasa saling percaya antara pemilik dana dan pengelola dana investasi (mudharib) dan (4) Fathanah, yaitu memastikan bahwa pengelolaan bank dilakukan secara profesional dan kompetitif sehingga menghasilkan keuntungan maksimum dalam tingkat resiko yang ditetapkan oleh bank Termasuk didalamnya adalah pelayanan yang penuh dengan kecermatan dan kesantunan (ri'ayah) serta penuh rasa tanggung jawab (masuliyah)

Dalam perspektif makro, nilai-nilai syari'ah menghendaki perbankan syari'ah harus berkontribusi bagi kesejahteraan masyarakat dengan memenuhi hal-hal antara lain sebagai berikut $^{11}$ : (1) Kaidah zakat, mengkondisikan perilaku masyarakat yang lebih menyukai berinvestasi dibandingkan hanya menyimpan hartanya, (2) Kaidah pelarangan riba, menganjurkan pembiayaan bersifat bagi hasil (equity based financing) dan melarang riba, (3) Kaidah pelarangan judi atau maysir tercermin dari kegiatan bank yang melarang investasi yang tidak memiliki kaitan dengan sektor riil dan (4) Kaidah pelarangan gharar (uncertainty), mengutamakan transparansi dalam bertransaksi dan kegiatan operasi lainnya dan menghindari ketidakjelasan.

Berdasarkan prinsip-prinsip syari'ah tersebut, sistem perbankan syari'ah yang ingin diwujudkan oleh Bank Indonesia adalah perbankan syari'ah yang modern, yang bersifat universal, terbuka bagi seluruh masyarakat Indonesia tanpa kecuali. Dengan positioning khas perbankan syari'ah sebagai "lebih dari sekedar bank" (beyond banking), yaitu perbankan yang menyediakan produk dan jasa keuangan yang lebih beragam serta didukung oleh skema keuangan yang lebih bervariasi.

Pada wilayah tinjauan hukum materilnya, perbankan konvensional dengan perbankan syari'ah pasti sangat berbeda. Hukum perbankan konvensional didasari oleh prinsip penetapan bunga yang dibawa oleh sistem ekonomi kapitalis, dengan filosofi "uang memiliki nilai waktu" (time value of money). Sedangkan hukum perbankan syari'ah mempunyai filosofi berbeda dengan prinsip perbankan konvensional tersebut. Dimana Islam memandang sebaliknya, uang hanyalah alat penukaran yang tidak memiliki "nilai waktu". Karena itu, berapapun besarnya tingkat suku bunga tetap saja diharamkan. Dalam Qur'an Surat AlBaqarah : 275, disebutkan bahwa :

“ Orang-orang yang makan (mengambil riba") tidak dapat berdiri melainkan seperti berdirinya orang yang kemasukan syaitan lantaran (tekanan) penyakit gila. Keadaan mereka yang demikian itu, adalah disebabkan mereka berkata (berpendapat), sesungguhnya jual beli itu sama dengan riba, padahal Allah telah menghalalkan jual beli dan mengharamkan riba. Orang-orang yang telah sampai kepadanya larangan dari Tuhannya, lalu terus berhenti (dari mengambil riba), maka baginya apa yang diambilnya dahulu (sebelum datang larangan); dan

\footnotetext{
${ }^{11}$ Ibid. 171

${ }^{12}$ Riba secara literal berarti semakna dengan kata ziyadah (tambahan). Dalam pengertian lain secara linguistic, riba berarti tumbuh dan membesar. Menurut istilah, riba berarti pengambilan tambahan dari harta pokok atau modal secara tidak sah (bathil). Secara garis besar riba dikelompokkan menjadi dua, yaitu riba utangpiutang (riba duyun) dan riba jual beli (riba buyu'). Riba yang dimaksud dalam ayat ini Riba nasi-ah yang berlipat ganda yang umum terjadi dalam masyarakat Arab jaman jahiliyah.
} 
urusannya (terserah) kepada Allah, Orang yang mengulangi (mengambil riba),maka orang itu adalah penghuni-penghuni neraka; mereka kekal di dalamnya". ${ }^{13}$

Hal inilah yang menjadi pembeda mendasar antara bank konvensional dengan bank syari'ah. Pada aspek teknis operasionalnya, seperti teknik penerimaan uang, mekanisme transfer, teknologi komputer yang diterapkan serta syarat-syarat umum untuk memperoleh pembiayaan, bank konvensional dengan bank syari'ah dapat menemui beberapa persamaan. Namun demikian dalam aspek-aspek tertentu keduanya memiliki perbedaan yang sangat prinsipil.

\section{2. $\quad$ Prinsip Good Corporate Governance}

Menurut Bank Dunia GCG adalah aturan, standar dan organisasi di bidang ekonomi yang mengatur perilaku pemilik perusahaan, direktur dan manajer serta perincian dan penjabaran tugas dan wewenang serta pertanggungjawabannya kepada investor (pemegang saham dan kreditur). Tujuan utama dari GCG adalah untuk menciptakan sistem pengendalian dan keseimbangan (check and balances) untuk mencegah penyalahgunaan dari sumber daya perusahaan dan tetap mendorong terjadinya pertumbuhan perusahaan. ${ }^{14}$

Dalam konteks perusahaan, istilah corporate governance diasosiasikan dengan kewajiban direksi kepada perusahaan untuk menjamin bahwa dirinya akan memenuhi semua kewajibannya sesuai dengan kewajiban yang dibebankan kepadanya dan juga menjamin bahwa kegiatan bisnis perusahaan tersebut akan dilaksanakan hanya demi kepentingan perusahaan semata. ${ }^{15}$ Kemudian, istilah corporate governance menjadi lebih luas lagi, tidak hanya meliputi kewajiban direksi terhadap perusahaan, tetapi kewajiban direksi kepada perusahaan secara keseluruhan, yang meliputi pemegang saham. Dalam hal ini direksi memberikan jaminan bahwa perusahaan akan memenuhi seluruh kewajibannya pada para pemegang sahamnya. Perusahaan akan dikendalikan dan dijalankan oleh direksi hanya dengan tujuan untuk menambah nilai kekayaan pemegang saham. ${ }^{16}$

Menurut Sutan Remi Sjahdeini, corporate governance adalah suatu konsep yang menyangkut struktur perseroan, pembagian tugas, pembagian kewenangan dan pembagian beban tanggung jawab dari masing-masing unsur yang membentuk struktur perseroan dan mekanisme yang harus ditempuh oleh masing-masing unsur dari struktur perseroan tersebut. Konsep ini juga menyangkut hubungan-hubungan antara unsur-unsur dari struktur perseroan itu, mulai dari RUPS, direksi, komisaris, juga mengatur hubungan-hubungan antara unsurunsur dari struktur perseroan dengan unsur-unsur di luar perseroan yang pada hakekatnya merupakan stakeholder dari perseroan, yaitu negara yang sangat berkepentingan akan perolehan pajak dari perseroan yang bersangkutan dan masyarakat luas yang meliputi para investor publik dari perseroan itu (dalam hal perseroan merupakan perusahaan publik), calon investor, kreditur dan calon kreditur perseroan. Dengan demikian dapat dikatakan bahwa corporate governance merupakan suatu konsep yang luas. ${ }^{17}$

Bacelius Ruru memberikan pengertian GCG atau tata kelola usaha yang baik, sebagai berikut:

13 Departemen Agama RI, Yayasan Penyelenggara Penterjemah Al-Qur'an, Al Qur'an Dan Terjemahnya, Semarang, CV.Toha Putra, 1989, hal. 69.

${ }^{14} \mathrm{http} / /$ tazkiaonline.com/?view=articles\&id=13\&detail=yes diakses rabu-/ 10-06-2009

15 Kala Anandarajah, The New Corporate Governance Code in Singapore" dikutip dalam Ridwan Khairandy dan Camelia Malik, Good Corporate Governance Perkembangan Pemikiran dan Implementasinya di Indonesia Dalam Perspektif Hukum, Yogyakarta, Kreasi Total Media, 2007, hal.61.

${ }^{16}$ Ibid

${ }^{17}$ Misahadi Wilamarta, Hak Pemegang Saham Minoritas dalam rangka Good Corporate Governance, Jakarta, Program Pasca Sarjana Fakultas Hukum Universitas Indonesia, 2002, hal. 2 
"Good corporate governance pada dasarnya merupakan suatu mekanisme yang mengatur tentang tata cara pengelolaan perusahaan berdasarkan rules yang menaungi perusahaan, seperti anggaran dasar (articles of association) serta aturan-aturan tentang perusahaan (UUPT), dan aturan-aturan yang mengatur tentang kegiatan perusahaan dalam menjalankan usahanya. Dengan demikian, sebenarnya good corporate governance bukan saja berkaitan dengan hubungan antara perusahaan dengan pemiliknya (pemegang saham), tapi juga (dan terutama) dengan para pihak yang mempunyai kepentingan dengan perusahaan (stakeholders).,$" 18$

Pengertian secara hukum mengenai GCG, dapat kita ketahui dari ketentuan pasal 1 angka 6 Peraturan Bank Indonesia Nomor 8/4/PBI/2006 tentang Pelaksanaan Good Corporate Governance bagi Bank Umum, yaitu :

Good corporate governance adalah suatu tata kelola bang yang menerapkan prinsip-prinsip keterbukaan (transparency), akuntabilitas (accountability), pertanggungjawaban (responsibility), independency (independency), dan kewajaran (fairness) ${ }^{19}$

Dalam sektor perbankan, Undang-Undang Perbankan secara prinsip juga telah mengatur aspek good corporate governance, seperti governance structure, governance process maupun governance outcome. Pada tahun 2004, Komite Nasional Kebijakan Corporate Governance telah mengeluarkan Pedoman Good Corporate Governance Perbankan Indonesia. Pedoman ini merupakan pelengkap dan bagian tak terpisahkan dari Pedoman Umum Good Corporate Governance yang dikeluarkan oleh Komite Nasional Kebijakan Corporate Governance dan dimaksudkan sebagai pedoman khusus bagi perbankan untuk memastikan terciptanya bank dan sistem perbankan yang sehat.

Di dalam perbankan syari'ah, pelaksanaan GCG pada dasarnya bertumpukan kepada lima pilar utama, yaitu : transparancy (keterbukaan, kejujuran), responsibility (pertanggungjawaban), accountability (akuntabilitas), fairness (kewajaran atau keadilan), dan independency (kemandirian atau kebebasan). Secara yuridis prinsip-prinsip tersebut sesuai dengan prinsip-prinsip GCG yang telah ditetapkan oleh BI dalam Peraturan Bank Indonesia (PBI) No. 8/4/PBI/2006 sebagaimana telah diubah dalam Peraturan Bank Indonesia No. 8/14/PBI/2006 tentang Pelaksanaan Good Corporate Governance bagi Bank Umum. Lima prinsip itu adalah ; transparansi, akuntabilitas, pertanggungjawaban, independensi dan kewajaran. ${ }^{20}$

Bank adalah lembaga intermediasi yang dalam menjalankan kegiatan usahanya bergantung pada dana masyarakat dan kepercayaan baik dari dalam maupun luar negeri. Dalam menjalankan kegiatan usaha tersebut bank selalu akan menghadapi resiko maupun pendapatan (risk and return). Secara garis besar resiko dapat digolongkan menjadi 2 macam, yaitu : resiko yang sistematis (systematic risk) dan resiko yang non sistematis (unsystematic risk) ${ }^{21}$. Adapun resiko yang mungkin dihadapi bank syari'ah adalah resiko modal, resiko pembiayaan, resiko operasional maupun resiko likuiditas ${ }^{22}$. Banyaknya ketentuan yang mengatur sektor perbankan dalam rangka melindungi kepentingan masyarakat, termasuk ketentuan yang mengatur kewajiban untuk memenuhi modal minimum sesuai dengan

\footnotetext{
${ }^{18}$ Bacelius Ruru, Good Corporate Governance dalam nasyarakat Bisnis Indonesia, sekarang dan Masa Mendatang, paper, diakses tanggal 20 Januari 2010 dari Http://www.nccgindonesia.org/lokakarya/yogyaruru.html

19 Bank Indonesia, Peraturan Bank Indonesia Nomor 8/4/PBI/2006 tentang Pelaksanaan Good Corporate Governance bagi Bank Umum, Jakarta, Bank Indonesia, 2006

${ }^{20}$ Menata Bank dengan Good Corporate Governance, BEI News Edisi 19 Tahun V, Maret 2004

${ }^{21}$ Systematic risk ialah resiko yang diakibatkan oleh adanya kondisi atau situasi tertentu yang bersifat makro, seperti perubahan situasi politik, perubahan kebijakan ekonomi pemerintah, perubahan situasi pasar, situasi krisis atau resesi yang berdampak pada kondisi ekonomi secara umum. Sedangkan unsystemic risk ialah resiko yang unik yang melekat pada suatu perusahaan atau bisnis tertentu saja.

${ }_{22}$ Muhammad, Manajemen Bank Syari’ah, Yogyakarta, UPP AMP YKPN, Edisi Revisi 2005, hal. 358
} 
kondisi masing-masing bank, menjadikan sektor perbankan sebagai sektor yang "highly regulated".

3. Good Corporate Governance Perbankan Syari'ah Indonesia

Pelaksanaan good corporate governance (GCG) sangat diperlukan untuk membangun kepercayaan masyarakat dan dunia internasional sebagai syarat mutlak bagi dunia perbankan untuk berkembang dengan baik dan sehat. Oleh karena itu Bank for International Settlements (BIS) ${ }^{23}$ sebagai lembaga yang mengkaji terus menerus prinsip kehati-hatian yang harus dianut oleh perbankan, telah pula mengeluarkan Pedoman Pelaksanaan GCG bagi dunia perbankan secara internasional. Pedoman serupa dikeluarkan pula oleh lembaga-lembaga internasional lainnya.

Sebagai lembaga intermediasi dan lembaga kepercayaan, dalam melaksanakan kegiatan usahanya bank harus menganut prinsip keterbukaan (transparency), memiliki ukuran kinerja dari semua jajaran bank berdasarkan ukuran-ukuran yang konsisten dengan corporate values, sasaran usaha dan strategi bank sebagai pencerminan akuntabilitas bank (accountability), berpegang pada prudential banking practices dan menjamin dilaksanakannya ketentuan yang berlaku sebagai wujud tanggung-jawab bank (responsibility), objektif dan bebas dari tekanan pihak manapun dalam pengambilan keputusan (independency), serta senantiasa memperhatikan kepentingan seluruh stakeholders berdasarkan azas kesetaraan dan kewajaran (fairness) ${ }^{24}$. Indictor-indikator GCG pada bank syari'ah dapat dijelaskan sebagai berikut: Pertama. Keterbukaan (Transparency), bentuk dari keterbukaan bank syariah antara lain : bank syari'ah harus mengungkapkan informasi secara tepat waktu, memadai, jelas, akurat dan dapat diperbandingkan serta mudah diakses oleh stakeholders sesuai dengan hakny, Informasi yang harus diungkapkan meliputi tapi tidak terbatas pada hal-hal yang bertalian dengan visi, misi, sasaran usaha dan strategi perusahaan, kondisi keuangan, susunan dan kompensasi pengurus, pemegang saham pengendali, cross shareholding, pejabat eksekutif, pengelolaan resiko (risk management), sistem pengawasan dan pengendalian intern, status kepatuhan, sistem dan pelaksanaan GCG serta kejadian penting yang dapat mempengaruhi kondisi bank syari'ah, prinsip keterbukaan yang dianut oleh bank tidak mengurangi kewajiban untuk memenuhi ketentuan rahasia bank sesuai dengan peraturan perundang-undangan yang berlaku, rahasia jabatan, dan hak-hak pribadi serta kebijakan bank syari'ah harus tertulis dan dikomunikasikan kepada pihak yang berkepentingan (stakeholders) dan yang berhak memperoleh informasi tentang kebijakan tersebut. ${ }^{25}$

Kedua. Akuntabilitas (Accountability), wujud dari akuntabilitas bank syari'ah berupa: bank syari'ah harus menetapkan tanggung jawab yang jelas dari masing-masing organ organisasi yang selaras dengan visi, misi, sasaran usaha dan strategi perusahaan, bank syari'ah harus meyakini bahwa semua organ organisasi bank mempunyai kompetensi sesuai dengan tanggung jawabnya dan memahami perannya dalam pelaksanaan GCG,

${ }^{23}$ The Bank for International Settlements (BIS) adalah organisasi internasional yang bergerak dalam kerja sama bank sentral di bidang keuangan dan moneter internasional. Organisasi tersebut didirikan pada 17 Mei 1930. BIS sebenarnya didirikan sebagai salah satu usaha untuk menciptakan kerjasama internasional mengenai masalah keuangan, diantaranya, menyangkut hal yang berhubungan dengan pampasan dan utang perang. Organisasi ini dimaksudkan untuk menyelesaikan pembayaran oleh para pihak yang berhutang kepada negara-negara lain di dunia, juga untuk dapat berperan sebagai bank sentral bagi bank-bank sentral yang ada, serta mengusahakan jalinan kerja sama diantara bank sentral di dunia. Peran yang sekarang menonjol dari BIS, yaitu sebagai lembaga yang menjalankan penelitian dan pengembangan tentang masalah-masalah keuangan dunia.

24 Komite Nasional Kebijakan Corporate Governance, Pedoman Good Corporate Governance Perbankan Indonesia, 2004

${ }^{25}$ Ibid 
bank syari'ah harus memastikan terdapatnya check and balance system dalam pengelolaan bank serta bank syari'ah harus memiliki ukuran kinerja dari semua jajaran bank berdasarkan ukuran-ukuran yang disepakati konsisten dengan nilai perusahaan (corporate values), sasaran usaha dan strategi bank serta memiliki rewards and punishment system ${ }^{\mathbf{2 6}}$.

Ketiga. Tanggung Jawab (Responsibility), artinya, bank syari'ah harus memegang prinsip prudential banking practices. Prinsip ini harus dijalankan sesuai dengan ketentuan yang berlaku, agar operasional perbankan syari'ah tetap berjalan sesuai dengan yang diharapkan. Bank pun harus mampu bertindak sebagai good corporate citizen (perusahaan yang baik). ${ }^{27}$

Keempat. Independensi (Independency), Penerapan prinsip Independensi, maka bank harus mampu menghindari terjadinya dominasi yang tidak wajar oleh stakeholders. Pengelola bank tidak boleh terpengaruh oleh kepentingan sepihak. Ia harus bisa menghindari segala bentuk benturan kepentingan (conflict of interest). Dalam hal terjadi benturan kepentingan, anggota dewan komisaris, anggota direksi, dan pejabat eksekutif dilarang mengambil tindakan yang dapat merugikan bank atau mengurangi keuntungan bank dan wajib mengungkapkan benturan kepentingan dimaksud dalam setiap keputusan. ${ }^{\mathbf{2 8}}$

Kelima. Kewajaran (Fairness), bank syari'ah harus memperhatikan kepentingan seluruh stakeholders berdasarkan azas kesetaraan dan kewajaran (equal treatment). Namun bank juga harus memberikan kesempatan kepada seluruh stakeholders untuk memberikan masukan bagi kepentingan bank sendiri serta memiliki akses terhadap informasi sesuai dengan prinsip keterbukaan. ${ }^{29}$

Para stakeholder perbankan syari'ah merupakan pemegang posisi kunci karena pertama, sebuah organisasi Islam harus melayani Allah dan mengembangkan budaya korporasi yang khas. Kedua, bank harus memberikan dan merancang instrumen dan produk keuangan syari'ah. Dalam kedua aspek itulah konsep pelayanan sangat cocok digunakan untuk memahami perilaku pihak-pihak yang terlibat dalam organisasi. Konsep amanah dalam islam menegaskan bahwa "segala harta adalah milik Allah, dan manusia, secara individu atau kolektif, adalah penjaganya. Harta hanya dapat dipergunakan untuk tujuan-tujuan yang telah ditentukan. Agar tercipta corporate governance yang efektif pada perbankan syari'ah maka, anggota Dewan Direksi harus memiliki reputasi moral yang baik dan kompetensi teknis yang mendukung. Selain itu mereka juga harus memiliki kesadaran yang penuh terhadap segala resiko, memiliki kemampuan untuk mengelola resiko seiring dengan kompleksitas bisnis perbankan. Untuk memilih anggota dewan direksi diperlukan standar profesionalisme tertentu, untuk menentukan layak tidaknya untuk menjadi dewan direksi dan juga memiliki pemahaman atas maqashid asy-syari'ah sebagai sebuah tuntutan Islam yang relevan dengan kegiatan bisnis keuangan.

Dewan Direksi bertanggung jawab atas beberapa fungsi manajemen tanpa harus terlibat secara langsung dalam operasionalisasi manajemen bank, sehingga ia harus memiliki agenda pertemuan rutin dengan seluruh komponen perusahaan, serta memiliki fungsi kontrol yang efektif. Dewan Direksi memiliki fungsi utama dalam manajemen, yakni menetapkan tujuan strategi dan prinsip-prinsip yang akan dijadikan sebagai acuan operasional bank. Selain

\footnotetext{
${ }^{26}$ Ibid

${ }^{27} \mathrm{http}: / /$ suaramerdeka.com/v1/index.php/read/cetak/2008/12/30/45384/Implementasi.GCG.pada.Bank.S yari'ah diakses Kamis 6 Agustus 2009

${ }^{28}$ Lihat ketentuan Pasal 60 Peraturan Bank Indonesia Nomor 8/4/PBI/2006 tentang Pelaksanaan Good Corporate Governance bagi Bank Umum.

${ }^{29}$ Muhamad Djumhana, Asas Asas Hukum Perbankan Indonesia, Bandung, PT Citra Aditya Bhakti, 2008, hal 224
} 
itu ia juga berperan dalam menetapkan kode etik bagi senior manajemen dan standar operasional yang akan menjadi budaya kerja perusahaan ${ }^{\mathbf{3 0}}$

Khusus bagi bank yang melakukan kegiatan usaha berdasarkan prinsip syari'ah, harus memiliki Dewan Pengawas Syari'ah, yaitu badan independen yang bertugas melakukan pengarahan (directing), pemberian konsultasi (consulting), melakukan evaluasi (evaluating), dan pengawasan (supervising) kegiatan bank syari'ah dalam rangka memastikan bahwa kegiatan usaha bank syari'ah tersebut mematuhi (compliance) terhadap prinsip syari'ah sebagaimana telah ditentukan oleh fatwa dan syari'ah islam. Stakeholders lainnya yang penting dari bank adalah deposan, penabung dan pemegang giro, debitur serta karyawan. Antara bank dengan stakeholders tersebut perlu dijalin hubungan bisnis sesuai dengan azas kesetaraan dan kewajaran berdasarkan ketentuan yang berlaku bagi masing-masing pihak. ${ }^{31}$

\section{PEMBAHASAN}

Secara umum, fungsi bank syari'ah sama dengan perbankan konvensional. Karena itu, prinsip-prinsip pokok GCG yang dikembangkan secara umum untuk sistem perbankan berlaku pula pada bank syari'ah. Dalam pandangan IFSB, cara pandang secara dikotomis antara pendekatan Islami dan konvensional dalam pengkajian standar GCG dinilai kurang tepat. Pada dasarnya prinsip-prinsip pokok dan best practices GCG yang dikembangkan pada perbankan syari'ah hampir sama dengan perbankan konvensional. Hal ini disebabkan karena secara umum, fungsi bank syari'ah sama dengan perbankan konvensional. Faktor-faktor yang perlu diperhatikan untuk mengembangkan konsep GCG diantaranya adalah kultur manajemen, akuntansi, dan pengawasan. Sebab, faktor-faktor tersebut nanti-nya dapat mempengaruhi berbagai hal, seperti perlindungan hak stakeholder. Istilah stakeholder dalam perbankan syari' ah mencakup pemegang saham, manajemen bank, karyawan, dan investment account holder (IAH). Investment account holder (IAH) merupakan nasabah atau deposan dalam perbankan konvensional.

Lembaga keuangan syari'ah, termasuk bank syari'ah secara inherent, merupakan lembaga yang seharusnya amanah, dan karenanya harus profesional, transparan, fair dan adil (termasuk dalam berbagi keuntungan) terhadap stakeholder, khususnya kepada para nasabahnya. Untuk itu, implementasi prinsip-prinsip good corporate governance (GCG) di berbagai lembaga bisnis berorientasi profit, khususnya lembaga keuangan/bank syari'ah, merupakan suatu keniscayaan, bahkan lembaga-lembaga keuangan syari'ah, khususnya bank syari'ah, harusnya menjadi pioneer dalam implementasi GCG, karena dijalankan menurut prinsip-prinsip Islam.

Prinsip-prinsip GCG sangat mendukung lembaga syari'ah karena memang sejalan dengan prinsip-prinsip syar'i seperti, antara lain: keadilan, transparansi, akuntabilitas, tanggungjawab, moralitas, komitmen, dan kemandirian. Sementara dalam Islam dikenal prinsip-prinsip muamalah seperti: keadilan, tazawun (keseimbangan), mas'uliyah (akuntabilitas), akhlaq (moralitas), Shiddiq (kejujuran), amanah (pemenuhan kepercayaan), Fathanah (kecerdasan), tabligh (transparansi, keterbukaan), hurriyah (independensi dan kebebasan yang bertanggungjawab, pemberdayaan), ihsan (profesional), wasathan (kewajaran), ghirah (militansi syari'ah), idarah (tata kelola), khilafah (kepemimpinan),

\footnotetext{
${ }^{30}$ M. Umer Chapra Dan Habib Ahmed, Corporate Governance; Lembaga Keuangan Syari'ah, Jakarta, PT Bumi Aksara, 2008 hal .42.

${ }^{31}$ Ibid
} 
aqidah (keimanan), ijabiyah (berfikir positif) raqabah (pengawasan), qira'ah dan islah (organisasi yang terus belajar dan selalu melakukan perbaikan) ${ }^{32}$.

Praktek moral hazard ${ }^{33}$ dan korupsi di berbagai lembaga perbankan, baik bank BUMN maupun bank swasta nampaknya sudah menjadi rahasia umum. Berbagai kejadian korupsi tersebut, harus menjadi perhatian serius bagi para stakeholders bank syari'ah, baik pemilik/ pemegang saham, komisaris, direksi, karyawan (kru,) Dewan Pengawas Syari'ah, nasabah dan para akademisi ekonomi syari'ah lainnya. Hal ini perlu menjadi perhatian penting, sebab saat ini lembaga perbankan syari'ah sedang menjadi idola dan berkembang sangat pesat di tanah air. Saat ini ada 29 Bank yang telah beroperasi secara syari'ah dan memiliki lebih dari 620 kantor di seluruh Indonesia. Ke depan, kemungkinan terjadinya korupsi dan penyimpangan di bank syari'ah merupakan hal tidak mustahil, meskipun di situ ada Dewan Pengawas Syari'ah, karena para pelakunya bukan malaikat. Apalagi sekarang ini perbankan syari'ah semakin banyak, maka para bankir syari'ah pun semakin bertambah banyak pula. Sehubungan dengan itu para jajaran eksekutif dan pejabat bank, bahkan termasuk komisaris harus ekstra hati-hati dalam mengelola lembaga perbankan syari'ah yang selalu dinilai "suci", karena berasal dari prinsip ilahiyah. Simbol agama tidak menjamin sebuah lembaga menjadi bersih dari perilaku korupsi.

Menurut Dhani Gunawan, korupsi di lembaga perbankan pada umumnya dapat menjelma dalam tiga bentukyaitu langsung, tidak langsung dan samar-samar (fuzzy). Bentuk korupsi langsung adalah pencurian uang pada bank oleh oknum individu atau kelompok dengan cara memanipulasi laporan keuangan, manipulasi dokumen dana bank atau dana nasabah, juga bisa dalam bentuk memark-up pembelian barang atau inventaris. Korupsi tidak langsung dapat berwujud dalam nepotisme tender barang atau jasa kepada sanak keluarga, sehingga bank dapat menjadi rugi, karena kualitas barang/jasa yang rendah. Atau oknum bankir mendapat komisi, atau sukses fee dari rekanan bank yang tidak dibukukan sebagai laba bank. Dana yang tak dibukukan ini diistilahkan dengan "dana taktis". Keberadaan dana taktis ini merupakan bibit awal korupsi, bibit awal rekayasa giant mark-up, karena dana taktis itu berasal dari anggaran bank yang kemudian berubah menjadi dana kepentingan pribadi atau oknum.Bentuk korupsi lainnya ialah seperti nepotisme penyaluran kredit yang mengurangi potensi pendapatan bank, nepotisme penerimaan pegawai atau promosi pegawai. Hal ini dapat menzalimi orang lain yang lebih baik, berkualitas dan lebih berhak. Sedangkan korupsi samar-samar merupakan bentuk yang paling potensial sering terjadi, karena berada di area abu-abu yang mudah disembunyikan, seperti komisaris atau direksi yang menggunakan mobil dinas mewah yang kemudian setelah penyusutan lalu dibeli menjadi miliknya dengan harga di bawah pasar.

Semua bentuk korupsi, baik langsung, tidak langsung maupun samar-samar adalah korupsi yang harus diberantas dengan aturan GCG (Good Corporate Governance) yang jelas. Karena itu, lembaga pengawasan, lembaga audit, dan masyarakat, harus tetap kritis terhadap bank syari'ah. Jangan terpana dengan label syari'ah, karena bisa saja lembaga memakai label syari'ah tetapi prakteknya tidak sepenuhnya syari'ah. Dalam konteks penerapan GCG di bank syari'ah, para bankir syari'ah, harus benar-benar merujuk kepada prinsip-prinsip dan nilainilai ekonomi dan bisnis Islam yang telah diterapkan oleh Rasulullah. Kalau tidak, jangan menjadi praktisi bankir syari'ah karena dikhawatirkan mereka hanya akan merusak citra

\footnotetext{
${ }^{32}$ http://agustianto.niriah.com/2008/03/11/good-corporate-governance-di-bank-syari\%E2\%80\% 99ah/ diakses Minggu - 15 Februari 2010

${ }^{33}$ Moral hazard merupakan resiko penyampaian informasi yang tidak sesuai dengan kenyat6aan oleh peminjam kepada pemberi pinjaman dengan tujuan untuk mendapatkan manfaat moneter. Moral hazard ini adalah masalah riil yang terjadi dalam hubungan antasra peminjam dan pemberi pinjaman, bukan hanya ada dalam analisis teoritis. Dengan adanya moral hazard, terbuka peluang munculnya inefisiensi di pasar uang karena informasi asimetris.
} 
"kesucian" syari'ah di masa yang akan datang. Nabi Muhammad adalah pelopor penegakan moral dalam setiap aspek kehidupan. Ia bersabda, "Sesungguhnya aku diutus untuk menyempurnakan akhlak". Prinsip-prinsip dan nilai-nilai bisnis yang diajarkan dan dipraktekkan Nabi Muhammad Saw tersebut sangat identik dengan spirit GCG yang dikembangkan saat ini.

Menurut Adiwarman Karim GCG adalah satu hal yang sangat penting. Sebab, dikhawatirkan, kalau perbankan syari'ah dalam proses analisis pembiayaannya tidak sempurna, akan menimbulkan banyak masalah nantinya. ${ }^{34}$ Sedangkan menurut Nurdin Hasibuan, ekspansi bisnis syari'ah harus diikuti dengan penerapan GCG. "Dalam rangka ekspansi yang begitu luas, dengan meminimalisasi kualitas pembiayaan yang tidak baik, maka tidak bisa tidak, adalah bagaimana kita menerapkan good corporate governance dengan benar. Dengan menerapkan GCG, bank syari'ah akan mampu meningkatkan akurasi penilaian bank, infrastruktur, kualitas pengambilan keputusan bisnis, dan mempunyai sistem deteksi dini terhadap high risk business area, product, dan services. Pada dasarnya, GCG adalah implementasi visi dan misi perbankan syari'ah. Point utama yang menjadi acuan dari visi ini adalah memenuhi prinsip kehati-hatian (prudential banking). Sedangkan, point misinya adalah mempersiapkan konsep serta melaksanakan pengaturan dan pengawasan berbasis resiko untuk menjamin kesinambungan operasi perbankan syari'ah yang sesuai dengan karakteristiknya. ${ }^{35}$

Penerapan good corporate governance pada umumnya dapat membantu mengebalkan perusahaan dari kondisi-kondisi yang tidak menguntungkan, disamping itu juga dapat meningkatkan kinerja corporate. Menurut Iman Sjahputra Tunggal, penerapan good corporate governance memberikan manfaat, yaitu 1) Perbaikan dalam komunikasi; 2) Minimisasi potensial benturan; 3) Fokus dan strategi -strategi utama; 4) Peningkatan dalam produktivitas dan efisiensi; 5) Kesinambungan manfaat (sustainability of benefits); 6) Promosi citra corporate (corporate image); 7)Peningkatan kepuasan pelanggan; dan 8) Perolehan kepercayaan investor. ${ }^{36}$

Bagi perbankan syari'ah, GCG harus dipandang sebagai asset dan memerlukan komitmen untuk menjalankannya, sehingga dalam perkembangan selanjutnya, prinsip GCG ini berlaku juga sebagai strategi investasi. Kultur governance harus ditumbuhkan termasuk dalam aspek pengambilan keputusan pada suatu manajemen. Implementasi GCG begitu penting, karena menurut Mutamimah Perbankan syari'ah merupakan lembaga intermediasi yang amat membutuhkan kepercayaan masyarakat agar dipercaya seluruh stakeholders. Bank syari'ah mempunyai beberapa keunikan, yaitu: a) stakeholders yang lebih menyebar, b) informasi asimetrinya sangat tinggi, c) sulit memonitor serta mengakses kinerja dan resiko operasional bank syari'ah, d) mempunyai tingkat leverage yang tinggi, e) klaim bersifat jangka pendek dan rentan terhadap rush, dan f) tingkat regulasinya juga sangat tinggi. Oleh karena itu, bank syari'ah perlu menerapkan CGC, karena bisa mempengaruhi penilaian dan menurunkan cost of capital, mempengaruhi kinerja bank, reputasi bank, dan pengambilan resiko bank, serta meminimisasi resiko krisis keuangan, baik untuk bank secara individual maupun bagi sistem bank secara keseluruhan ${ }^{37}$.

${ }^{34}$ InfoBankNews.com, Menunggu Belied Good Corporate Governance, 12 April 2005, diakses Senin 5 Oktober 2009, hal 12.

${ }^{35}$ Ibid

${ }^{36}$ Iman Sjahputra Tunggal dan Amin Widjaja Tunggal, Memahami Konsep Corporate Governance, dalam Hesel Nogi S Tangkilisan, Manajemen Keuangan Bagi Analisis Kredit Perbankan Mengelola Kredit Berbasis Good Corporate Governance, Yogyakarta, Balairung \& Co., 2003, hal. 112

${ }^{37} \mathrm{http}: / /$ suaramerdeka.com/v1/index.php/read/cetak/2008/12/30/45384/Implementasi.GCG.pada.Bank.S yari'ah diakses Kamis 5 November 2009 
Menurut Johan Arifin Penerapan GCG pada bank syari'ah diharapkan: (1) semakin meningkatnya kepercayaan publik kepada bank syari'ah, (2) pertumbuhan industri jasa keuangan Islam dan stabilitas sistem keuangan secara keseluruhan akan senantiasa terpelihara, dan (3) keberhasilan industri jasa keuangan Islam dalam menerapkan GCG akan menempatkan lembaga keuangan Islam pada level of playing field yang sejajar dengan lembaga keuangan internasional ${ }^{38}$

Untuk itu, implementasi prinsip-prinsip good corporate governance (GCG) di berbagai lembaga bisnis berorientasi profit, khususnya lembaga keuangan/bank syari'ah, merupakan suatu keniscayaan, bahkan lembaga-lembaga keuangan syari'ah, khususnya bank syari'ah, harusnya menjadi pioneer dalam implementasi GCG Keharusan tampilnya bankir syari'ah sebagai pioneer penegakan GCG dibanding konvensional, karena permasalahan governance dalam perbankan syari'ah ternyata sangat berbeda dengan bank konvensional. Pertama, bank syari'ah memiliki kewajiban untuk mematuhi prinsip-prinsip syari'ah (shariah compliance) dalam menjalankan bisnisnya. Karenanya, Dewan Pengawas Syari'ah (DPS) memainkan peran yang penting dalam governance structure perbankan syari'ah. Kedua, karena potensi terjadinya information asymmetry sangat tinggi bagi perbankan syari'ah maka permasalahan agency theory menjadi sangat relevan. Hal ini terkait dengan permasalahan tingkat akuntabilitas dan transparansi penggunaan dana nasabah dan pemegang saham. Karenanya, permasalahan keterwakilan investment account holders dalam mekanisme good corporate governance menjadi masalah strategis yang harus pula mendapat perhatian bank syari'ah. Ketiga, dari perspektif budaya korporasi, perbankan syari'ah semestinya melakukan transformasi budaya di mana nilai-nilai etika bisnis Islami menjadi karakter yang inheren dalam praktek bisnis perbankan syari'ah. ${ }^{39}$

\section{PENUTUP}

Implementasi prinsip-prinsip good corporate governance (GCG) di berbagai lembaga bisnis berorientasi profit, khususnya lembaga keuangan/bank syari'ah, merupakan suatu keniscayaan, bahkan lembaga-lembaga keuangan syari'ah, khususnya bank syari'ah, harusnya menjadi pionir dalam implementasi GCG, karena dijalankan menurut prinsip-prinsip Islam. Di samping itu juga karena semakin kompleksnya resiko yang dihadapi bank, untuk meningkatkan kinerja Bank, melindungi kepentingan stakeholders dan meningkatkan kepatuhan terhadap peraturan perundang-undangan yang berlaku serta nilai-nilai etika yang berlaku umum pada industri perbankan,untuk memperkuat kondisi internal perbankan nasional sesuai dengan Arsitektur Perbankan Indonesia. Penerapan GCG begitu penting, karena perbankan syari'ah merupakan lembaga intermediasi yang amat membutuhkan kepercayaan masyarakat agar dipercaya seluruh stakeholders.

Karena budaya hukum perbankan nasional cenderung didominasi oleh perbankan yang berbasis konvensional, maka untuk menciptakan iklim yang sehat bagi penerapan GCG di bank syari'ah harus melibatkan seluruh stakeholders perbankan syari'ah secara luas. Tetapi harus dicatat, bahwa aktor paling menentukan adalah para bankir syari'ah itu sendiri. Mereka harus memiliki tekad dan komitmen yang kuat untuk mewujudkan GCG di lembaganya. Selain itu, keterlibatan semua pihak sangat diperlukan dalam hal ini, yaitu melalui kerja sama yang harmonis antar alim ulama, nasabah bank, akademisi dan pemerintah untuk memacu kinerja bank syari'ah dalam mematuhi prinsip-prinsip GCG sehingga dapat membangun citra syari'ah sebagai uswah hasanah dan dapat memberikan kontribusi yang optimal dalam membangun perekonomian umat dan bangsa.

\footnotetext{
${ }^{38}$ http://tazkiaonline.com/?view=articles\&id=13\&detail=yes diakses rabu-/ 16 Desember 2009

${ }^{39} \mathrm{http} / / / \mathrm{www}$. rifkadejavu.com/index.php/2009/12/good-corporate-governance-di-bank-syari\%E2 \%80\%99ah/ diakses selasa 15 Desember 2009
} 


\section{DAFTAR PUSTAKA}

Anshori, Abdul Ghofur, Perbankan Syari'ah Di Indonesia, 2007, Gadjah Mada University Press, Yogyakarta.

Bank Indonesia, Arsitek Perbankan Indonesia, 2006, Bank Indonesia, Jakarta

Chapra, Umer M., Corporate Governance, Lembaga Keuangan Syari'ah, 2008, Bumi Aksara, Jakarta

Djumhana, Muhamad, Asas-Asas Hukum Perbankan Indonesia, 2008, Citra Aditya Bakti, Bandung

Gunawan Diredja, Tjahja, Industri Perbankan Syari'ah Perdebatan Dangkal Soal Riba, Kompas, Senin 11Februari 2008

Khairandy, Ridwan dan Camelia Malik, Good Corporate Governance Perkembangan Pemikiran dan Implementasinya di Indonesia Dalam Perspektif Hukum, 2007 Kreasi Total Media, Yogyakarta

Sjahdeini , Sutan Remy, Perbankan Islam dan Kedudukannya Dalam Tata Hukum Perbankan Indonesia, 2005, Pustaka Utama Grafiti, Jakarta.

Tunggal, Iman Sjahputra dan Amin Widjaja Tunggal, Memahami Konsep Corporate Governance, dalam Hesel Nogi S Tangkilisan, Manajemen Keuangan Bagi Analisis Kredit Perbankan Mengelola Kredit Berbasis Good Corporate Governance, 2003, Balairung \& Co., Yogyakarta

Wilamarta,Misahadi, Hak Pemegang Saham Minoritas dalam rangka Good Corporate Governance, 2002, Program Pasca Sarjana Fakultas Hukum Universitas Indonesia, Jakarta

Menata Bank dengan Good Corporate Governance, BEI News Edisi 19 Tahun V, Maret 2004

Undang-Undang No 21 Tahun 2008 tentang Perbankan Syari'ah

Peraturan Bank Indonesia (PBI) No. 8/4/PBI/2006 dan diubah dalam Peraturan Bank Indonesia No. 8/14/PBI/2006 tentang Pelaksanaan Good Corporate Governance bagi Bank Umum

Komite Nasional Kebijakan Corporate Governance, 2004, Pedoman Good Corporate Governance Perbankan Indonesia, Bank Indonesia.

InfoBankNews.com, Menunggu Beleid Good Corporate Governance, 12 April 2005, diakses Senin 5 Oktober 2009

http://agustianto.niriah.com/2008/03/11/good-corporate-governance-di-bank-syari\%E2\%80\% 99ah / diakses pada tanggal15 Februari 2010

Bacelius Ruru, Good Corporate Governance dalam Masyarakat Bisnis Indonesia, Sekarang dan Masa Mendatang, paper, diakses tanggal 20 Januari 2010 dari Http://www.nccg-indonesia.org/lokakarya/yogyaruru.html

http;/www.fiscal.depkeu.go.id/bapekki/klip/detailklip.asp?klipID=N267363402 diakses pada Tanggal 30 Pebruari 2010 
http://suaramerdeka.com/v1/index.php/read/cetak/2008/12/30/45384/Implementasi GCG pada Bank Syari'ah diakses pada Tanggal 6 Agustus 2009

http://ng.republika.co.id/berita/16813/Sejarah_Perkembangan_Industri_Perbankan_Syari'ah_ di_Indonesia diakses pada tanggal 2 Agustus 2009

http://tazkiaonline.com/?view=articles\&id=13\&detail=yes diakses pada Tanggal 16 Desember 2009

http://www.rifkadejavu.com/index.php/2009/12/good-corporate-governance-di-banksyari\%E2\%80\%99ah/ diakses pada Tanggal 15 Desember 2009 